\title{
Kajian Manfaat Senyawa Aktif dalam Ekstrak Kulit Buah Coklat (Theobroma Cacao )
}

\section{Studi of Benefits of Active Compounds in Cacao Pod Rind Extract (Theobroma Cacao)}

\author{
Sukatik $^{1)}$, Yuli Yetri ${ }^{1)}$, Rahmi Hidayati ${ }^{1)}$, Roni Tri Putra ${ }^{1)} \&$ Ratih Paramitha $^{2)}$ \\ ${ }^{1)}$ Politeknik Negeri Padang, Kampus Limau Manis, Padang, ${ }^{2}$ STIKes Nurliana Medan \\ Email: sukatikwiryosentono@gmail.com
}

\begin{abstract}
Identification of active compounds in cacao pod rind has been done. Cacao pod rind contained active compound alkaloid, theobromine (3,7-dimethylxanthine). Cacao pod rind extract contained some other active compounds mixed flavonoid or condensed tannin such as anthocyanin, anthocyanidin, catechin, epicatechin, epigallocatechin, and leucoanthocyanidin.

Cacao pod rind was extracted by maceration using methanol $70 \%$ and fractionated with hexane and ethyl acetate to obtain polar extracts. This study used an experimental method that was analyzed descriptively using Gas Chromatography-Mass Spectrometry (GC-MS) and Liquid Chromatography-Mass Spectrometry (LC-MS).

Phytochemical screening test showed cocoa pod rind extracts contained alkaloids, flavonoids, tannins, terpenoids, and saponins. GC-MS analysis showed that cacao pod rind extracts contained 24 compounds. Polar extracts analysis with LC-MS obtained 10 compounds contained hydroxy groups, which can be used as corrosion inhibitors on metal. The result of this study showed that cocoa pod rind has potential as corrosion inhibitor. It also has potential as an anti-bacterial and antioxidant.
\end{abstract}

Key words : Cocoa peel extract, Phytochemicals, Polar extrac, Corrosion inhibitors, Anti-bacterial

\section{PENDAHULUAN}

Indonesia adalah negara penghasil kakao nomor 3 terbesar di dunia setelah Ghana dan Pantai Gading (pidato Mentan 2012). Tanaman kakao mempunyai tinggi sekitar 5-10 m, batang berkayu (lignosus), bulat, percabangan monopodial, dan berwarna coklat kotor, dengan nama latinTheobroma cacao, dan termasuk dalam genus Theobroma. Bagian terbesar dari buah kakao terdiri dari kulit luar (mesokarp) yang keras yang mencapai $75 \%$, plasenta berwarna putih dan biji yang berwarna coklat. Peningkatan produksi buah kakao, akan mengakibatkan semakin meningkat pula kulit buah kakao yang dihasilkan. Kulit buah kakao adalah limbah industri perkebunan yang merupakan sumber energi dan protein yang cukup baik dengan kandungan protein 9$19 \%$ dan serat kasar $13-26 \%$, energi metabolis $2400 \mathrm{kkal} / \mathrm{kg}$, lemak 4,6\%, kalsium $0,61 \%$ dan fosfor $0,06 \%$ (Mulyatni A. S, et al, 2012).

Tumbuhan kakao mengandung senyawa tanin (Figuera, 2008). Tanin merupakan senyawa organik komplek yang terdiri dari polifenoldan mempunyai sejumlah gugus hidroksi dan adakalanya terdapat dalam bentuk glikosida. Selain itu kulit buah kakao diketahui mengandung senyawa aktif alkaloid yaitu theobromin(3,7- dimethylxantine) (Helmestein, 2010). Tannin yang terdapat dalam kulit buah kakao mengandung gugus aktif yang dapat berfungsi sebagai inhibitor korosi (Osman et al, 2004) (Yetri Y et al, 2015), antimikroba(Agni Rimba Mawan, 2018), dan antioksidan (Shanab, 2007). Senyawaaktif tersebut diketahui memiliki sifat antibakteri (Matsumoto et.al,2004).

Ekstrak kulit buah kakao mengandung beberapa komponen senyawa 
kimia antara lain campuran flavonoid atau tanin terkondensasi. Keberadaan senyawa tersebut di dalam kulit buah kakao diduga menjadi salah satu penyebab tidak ditemukannya penyakit tanaman kakao yang disebabkan oleh bakteri. Penelitian mengenai potensi ekstrak kulit buah kakao telah banyak dilakukan, salah satunya kulit buah kakao jenis lindak (Forastero) digunakan sebagai bahan anti bahteri (Mulyatni A.S,etal, 2012), anti oksidan dan obat (Andujar et al, 2012).

Dalam tulisan ini disampaikan cara yang efektif mengekstrak komponen kimia dari kulit buah kakao dan menganalisanya secara lebih lanjut komponen fitokimianya secara kualitatif maupun kuantitatif serta mengkaji potensi manfaat dari senyawa kimianya.

\section{METODOLOGI}

\section{Alat dan Bahan}

Peralatan yang dipakai dalam penelitian ini adalah seperangkat peralatan gelas, neraca analitik, jangka sorong digital, gerinda, oven, Heidolph WB 2000 rotary evaporator, hot plate, GC-MS QP2010S SHIMADZU, LC-MS-QMicro QAA 842, Perkin Elmer System 2000 Fourier Transform Infra Red Spectroscopy (FTIR).Bahan yang digunakan yaitu: kulit buah kakao segar, metanol teknis, aquades, aquabides, $\mathrm{HCl}$ p.a, aseton p.a, $\mathrm{FeCl}_{3}$, dan $\mathrm{H}_{2} \mathrm{SO}_{4}$, kloroform, amoniak etil asetat, Dragendorf, Meyer dan Wagner, Liebermen Burchard, asetat anhidrat dan nheksana.

\section{Pengujian fitokimia kulit buah kakao.}

Analisis fitokimia dilakukan berdasarkan Harbone (1987). Identifikasi yang dilakukan adalah uji alkaloid (Raman, 2006), uji flavonoid(Shanmugan et al., 2010), uji saponin (Depkes RI, 1989),uji triterpenoid dan uji steroid dengan pereaksi Liebermen Burchard, dan uji tannin/ fenolik(Kurin \& Sankar, 2007).

\section{Pembuatan ekstrak kulit buah kakao}

Proses pembuatan ekstrak kulit buah kakao, analisa FTIRdengan a Nicolet iS10FTIR spectrophotometer prosenya sama dengan yang sudah dilakukan pada penelitian terdahulu (Yetri Y., et al, 2015).

\section{Gas Chromatography-Mass Spectrometry dan Liquid Chromatography - Mass Spectrometry}

Untuk mengindentifikasi senyawa apa dan komposisi dari ekstrak kulit buah kakao dipelajari lebih dahulu dengan menggunakan gas chromatography mass spectrometry (GC-MS.)Pengujian dilakukan dengan GCMS-QP2010S SHIMADZU dengan parameter kolom:AGILENTJ\%WDB-1,Panjang 30 meter,ID: $0,25 \mathrm{~mm}$,gaspembawa:Helium, Pengionan: EI70Ev, model injeksi: Split, temperatur injeksi: $310{ }^{\circ} \mathrm{C}$, temperature kolom: $70^{\circ} \mathrm{C}$ dan maksimum $324^{\circ} \mathrm{C}$ selama 50 menit, aliran kolom: $0,5 \mathrm{ml} / \mathrm{min}$ kecepatan linear: $25.9 \mathrm{~cm} / \mathrm{sec}$.

Untuk memisahkanbeberapa senyawa atau campuran senyawa berdasarkan kepolarannya digunakan metode Liquid Chromatograpy-Mass Spectroscopy. Analisa terhadap ekstrak tersebut menggunakan LC-Qmicro QAA 842 dengan parameter initial sebagai berikut: kolom:repair phase, kelas kolom: standar polar, pelarut: methanol air, suhu kolom: $40^{\circ} \mathrm{C}$, suhu sampel: $20^{\circ} \mathrm{C}$, kecepatan: 0,4ml/min dan tekanan: 300 bar.

\section{Perendaman Besi dalam Larutan Media Korosi Tanpa Inhibitor 2.3.4.1}

Variasi pH Sampel besi yang telah disiapkan masing-masing direndam dalam

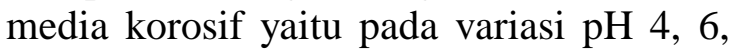
dan 8 selama 14 hari. Kemudian besi diambil lalu dibilas dengan $\mathrm{HCl} 1 \mathrm{~N}$ dan dimasukkan ke dalam oven dengan suhu 50-60oC selama 10 menit. Timbang besi sebagai berat akhir.

\section{HASIL DAN PEMBAHASAN}

\section{Pengujian fitokimia}

Hasil identifikasi senyawa kimia yang terkandung dalam ekstrak kulit buah kakao 
dilakukan dengan cara uji fitokimia. Hasil pengujian fitokimia menunjukan bahwa ekstrak kulit buah kakao mengandung senyawa metabolit sekunder seperti diperlihatkan pada Tabel 1.

Tabel 1: Fitokimia ekstrak kulit buah kakao

\begin{tabular}{|c|c|c|c|}
\hline Senyawa & Pereaksi & Warna & Keterangan \\
\hline Flavonoid & $\mathrm{H}_{2} \mathrm{SO}_{4}$ & Orange & ++++ \\
\hline Fenolik & $\mathrm{FeCl}_{3}$ & $\begin{array}{l}\text { Hijau } \\
\text { kehitaman }\end{array}$ & ++++ \\
\hline Terpenoid & $\begin{array}{l}\text { Lieberman } \\
\text { Burchard }\end{array}$ & Merah bata & + \\
\hline Saponin & Air & busa & +++ \\
\hline Steroid & $\begin{array}{l}\text { Lieberman } \\
\text { Burchrd }\end{array}$ & Hijau pudar & + \\
\hline Alkaloid & Meyer & $\begin{array}{l}\text { Putih sedikit } \\
\text { kabut }\end{array}$ & ++++ \\
\hline
\end{tabular}

Analisa Gas Chromatography-Mass Spectrometry (GC-MS)

Analisis GC-MS dilakukan untuk mengetahui jenis senyapa kimia yang terdapat dalam ekstrak kulit buah kakao. Hasil spektrum GC-MS ekstrak kulit buah kakao sebelum dilakukan fraksinasi menunjukan bahwa ekstrak kulit buah kakao mengandung 42 senyawa dominan (puncak spektrum) yang dapat dilihat pada Gambar 1 dan Tabel 2.

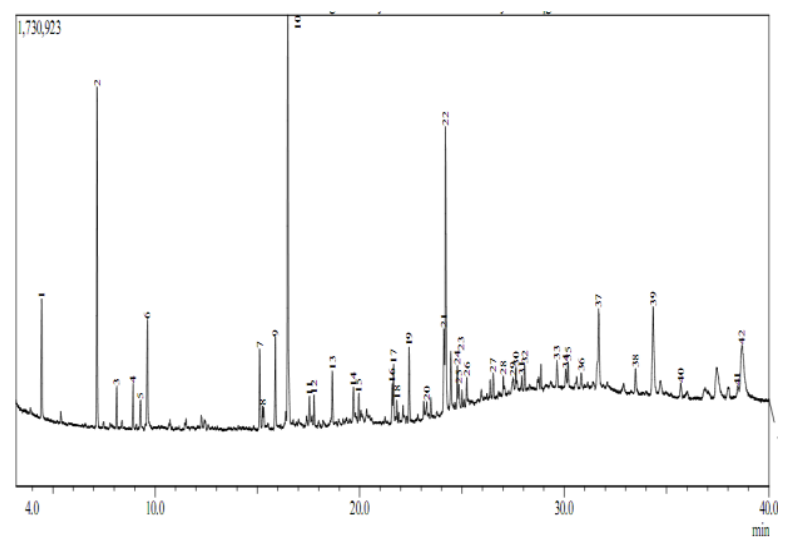

Gambar 1. Grafik hasil analisa ekstrak kulit buah kakao dengan GC-MS

Dari ke 42 senyawa tersebut, bila dikelompokkan terdiri atas: 3 dari gologan benzene, 1 amida, 5 asam karboksilat, 3 monoterpen, 1 aromatik, 5 alkana, 3 alkohol 2 keton dan 1 steroaid serta sisanya tidak dapat ditentuka karena tidak ditemukan literaturnya. Puncak senyawa phenolik tidak muncul, pada hal pada pengujian awal menunjukkan adanya senyawa phenolik yang ditandai munculnya warna biru pekat pada larutan setelah ditetesi dengan $\mathrm{FeCl}_{3}$, tetapi hasil analisis dengan GC-MS justru tidak menunjukkan adanya puncak fenolik. Hal ini mungkin disebabkan karena pengoperasian GC-MS menggunakan temperatur tinggi, sehingga senyawasenyawa phenolik sebelum temperatur operasi GC-MS tercapai, senyawasenyawa ini sudah menguap.<smiles>Oc1ccc2ccccc2c1-c1c(O)ccc2ccccc12</smiles>

Gambar 2. Salah satu rumus bangun senyawa Phenol

\section{Analisa Liquid Chromatography-Mass Spectroscopy (LC-MS)}

Hasil iidentifikasi ekstrak polar kulit buah kakao terdapat senyawa polar, maka dilakukan analisa lanjutan dengan menggunakan LC-MS. Identifikasi dengan LC-MS menghasilkan 10 puncak dominan seperti pada Gambar 3 berikut :

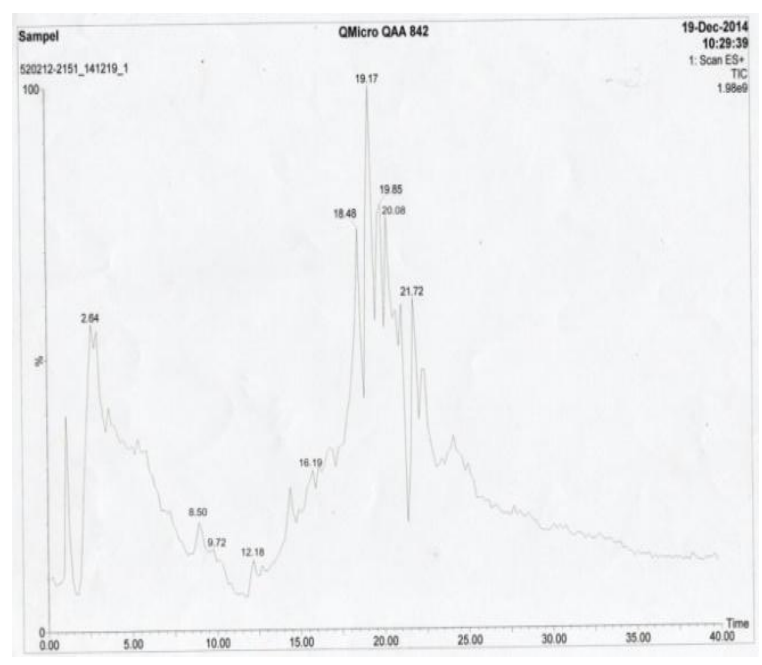

Gambar 3: Kromatogram hasil analisa ekstrak kulit buah kakao dengan LC-MS 
Kromatogram diatas menunjukkan adanya beberapa puncak yang memperlihatkan senyawa yang teridentifikasi dengan LC-MS mengandung senyawa dengan berat molekul tinggi berdasarkan ion fragmen dan ion molekul yang diperoleh dari data pengujian (Anujar et al, 2012, Velasco et al, 2014). Senyawa-senyawa tersebut mempunyai gugus heteroatom yang dapat berfungsi sebagai donor elektron (Sastri, 2011). Adapun senyawa-senyawa heteroatom yang terdapat dalam ekstraks kulit buah kakao seperti pada tabel 3 berikut :

Tabel 2: Senyawa hasil analisa ekstrak polar kulit buah kakao dengan LC-MS

\begin{tabular}{lcc} 
Nama senyawa & Formula & $\begin{array}{c}\text { Waktu retensi } \\
\text { (min) }\end{array}$ \\
\hline Quercetin & $\mathrm{C}_{15} \mathrm{H}_{10} \mathrm{O}_{7}$ & 2.64 \\
Catechin & $\mathrm{C}_{15} \mathrm{H}_{14} \mathrm{O}_{6}$ & 8.50 \\
Gallic acid & $\mathrm{C}_{7} \mathrm{H}_{6} \mathrm{O}_{5}$ & 9.72 \\
Epicatechin & $\mathrm{C}_{15} \mathrm{H}_{14} \mathrm{O}_{7}$ & 12.18 \\
Catechin & $\mathrm{C}_{15} \mathrm{H}_{14} \mathrm{O}_{6}$ & 16.19 \\
Caffeic acid derivate & $\mathrm{C}_{8} \mathrm{H}_{10} \mathrm{~N}_{4} \mathrm{O}$ & 18.48 \\
Salvianolic acid & $\mathrm{C}_{9} \mathrm{H}_{10} \mathrm{O}_{3}$ & 19.17 \\
Kampferol 3-O- & $\mathrm{C}_{15} \mathrm{H}_{10} \mathrm{O}_{6}$ & 19.85 \\
Rutinoside & & \\
Prosianidin $\mathrm{B} 2$ & $\mathrm{C}_{31} \mathrm{H}_{28} \mathrm{O}_{12}$ & 20.8 \\
Kampferol 3-O- & $\mathrm{C}_{53} \mathrm{H}_{56} \mathrm{O}_{28}$ & 21.72 \\
(Sinapoyl)- Sophoside & & \\
\hline
\end{tabular}

\section{Analisa Gugus Fungsi Dengan FTIR}

Pengujian gugus fungsi dengan FTIR bertujuan untuk mendukung data yang diperoleh dari analisa GC-MS dan LC-MS.

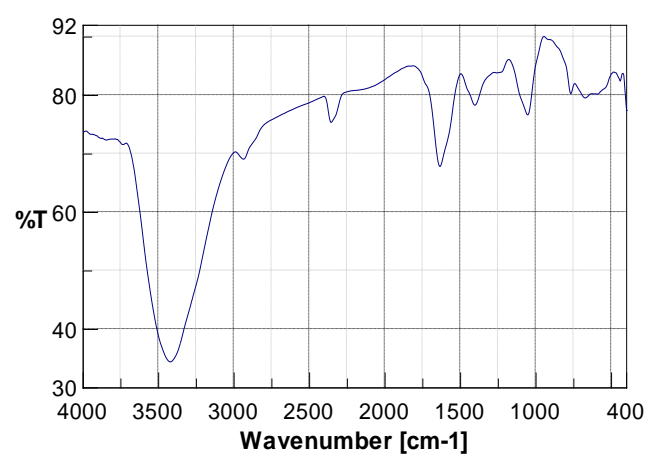

Gambar 4: Spektra FTIR Ekstrak kulit buah kakao

Spektrum FTIR gambar 4 berfungsi untuk memperkirakan gugus fungsi yang berkaitan dengan mekanisme adsorpsi molekul di permukaan baja. Selain dari pada itu juga berfungsi untuk mendukung data analisa GC-MS dan LC-MS (Singh et $a l, 2010$, Singh et al, 2012). Dari spektra diatas teridentifikasi beberapa puncak yang ada dan merupakan puncak gugus fungsi dan ditampilkan secara lengkap pada Tabel 4 berikut

Tabel 4: Analisa Spektra FT-IR dari ekstrak kulit buah kakao,

\begin{tabular}{cl}
\hline$v\left(\mathrm{~cm}^{-1}\right)$ & Gugus Fungsi \\
\hline & C-C $=$ C (aromatik) \\
1400 & dan C-C (aromatik \\
1051 & C-O (str) \\
& C=O (str) dan C-H \\
1603 & (str) \\
3422 & O-H (fenolik) \\
\hline
\end{tabular}

Identifikasi gugus fungsi ekstrak kulit buah kakao pada spektra hasil FT-IR adalah fenolik, cincin aromatik dan eter (Kim and Keeney, 1983). Bilangan gelombang $1051 \mathrm{~cm}^{-1}$ menunjukan gugus fungsi $\mathrm{C}-\mathrm{O}$ stretcing vibration. Puncak $1400 \mathrm{~cm}^{-1}$ menunjukan adanya ikatan $\mathrm{C}=\mathrm{C}$ aromatik. Munculnya puncak $1603 \mathrm{~cm}^{-1}$ menyatakan adanya gugus $\mathrm{C}=\mathrm{O}$ karbonil dan puncak $3422 \mathrm{~cm}^{-1}$ menunjukkan adanya gugus hidroksil $(\mathrm{C}-\mathrm{OH})$ pada senyawa yang terkandung dalam ekstrak buah kakao. Hasil FTIR menunjukkan puncak-puncak yang muncul pada spektrum mewakili sebagian gugus fungsi dari senyawa fenolik dan gugus fungsi lainnya hasil pengujian GC-MS seperti antosianin, antosianidin, katekin, epikatekin, epigallokatekin, dan leukoantosianidin (Okuda and Ito, 2011, Hii1 C. L et al, 2009) (Chung et al, 2003) (T. Alemanno et al, 2003).

\section{Analisis potensi manfaat dari senyawa kimia.}

Senyawa fenolik memiliki aktivitas biologik yang beraneka ragam, dan banyak digunakan dalam reaksi enzimatik oksidasi kopling sebagai substrat donor H. Reaksi oksidasi kopling, selain membutuhkan suatu oksidator juga memerlukan adanya suatu senyawa yang dapat mendonorkan 
H. Senyawa fenolik merupakan contoh ideal dari senyawa yang mudah mendonorkan atom $\mathrm{H}$.

Tannin yang terdapat dalam kulit buah kakao mengandung gugus aktif yang dapat berfungsi sebagai inhibitor korosi (Osman et al, 2004) (Yetri Y et al, 2015), antimikroba(Agni Rimba Mawan, 2018), dan antioksidan (Shanab, 2007). Senyawaaktif tersebut diketahui memiliki sifat antibakteri (Matsumoto et.al,2004).

Nilai LC50. Pengujian toksisitas terhadap ekstrak kulit biji kakao dilakukan menggunakan metode Brine Shrimp Lethality Test (BSLT) dengan larva Artemia salina sebagai hewan uji. Berdasarkan hasil pengujian, semakin tinggi konsentrasi ekstrak kulit biji kakao, semakin besar pula persentase kematian larva udang. Cara kerja senyawa-senyawa tersebut adalah dengan bertindak sebagai stomach poisoning atau racun perut. Suatu zat dikatakan aktif atau toksik bila nilai LC50 < 1000 ppm untuk ekstrak dan < 30 ppm untuk suatu senyawa (Meyer et al., 1982 dikutip Juniarti et al., 2009). Hasil perhitungan rata-rata LC50 menunjukkan bahwa nilai rata-rata LC50 ekstrak kulit biji kakao adalah 39.595,27 ppm, artinya ekstrak tersebut tidak bersifat toksik bagi larva Artemia salina. Jika hasil uji BSLT menunjukkan bahwa ekstrak tumbuhan bersifat toksik (LC50 < 1000 ppm) maka dapat dikembangkan untuk obat alternatif antikanker. Menurut Fowler (2009), kulit biji kakao dapat dimanfaatkan sebagai substitusi pada serbuk kakao untuk menambah kandungan seratnya. Ekstrak kulit biji kakao dapat dimanfaatkan sebagai antimikroba karena kandungan komponen fitokimianya. Kandungan komponen fenoliknya seperti tanin dan flavonoid berpotensi sebagai sumber antioksidan alami (Sartini dkk, 2009).

\section{Penentuan Laju Korosi}

Pengukuran laju korosi pada umumnya dilakukan dengan menggunakan metode kehilangan berat yang terjadi setelah beberapa waktu pencelupan. Dengan mengukur kembali berat benda uji, kekurangan berat berat awal merupakan nilai kehilangan berat (Mufid, 2015). Gambar adalah grafik kehilangan berat besi seiring bertambahnya salinitas yang menunjukkan bertambahnya persen (\%) kehilangan berat

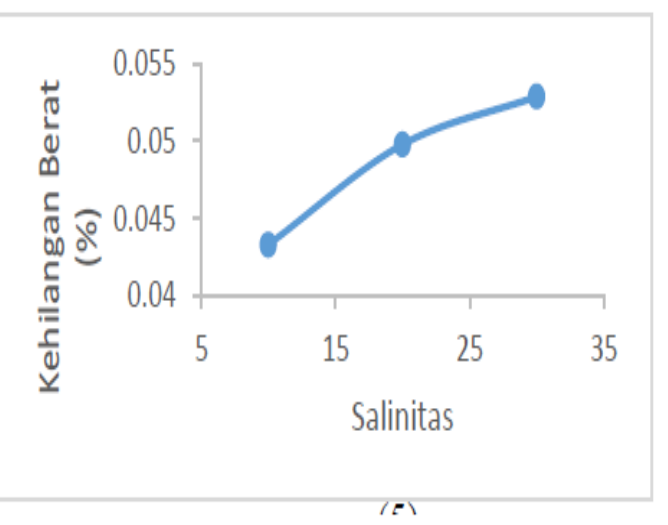

Gambar 5 . Grafik Hubungan salinitas terhadap kehilangan berat

Pengaruh Konsentrasi Inhibitor dan Salinitas terhadap laju Korosi Besi pada Media korosif air laut.

Gambar berikut menunjukkan laju korosi yang mengalami penurunan seiring dengan penambahan konsentrasi inhibitor ekstrak kulit buah kakao.

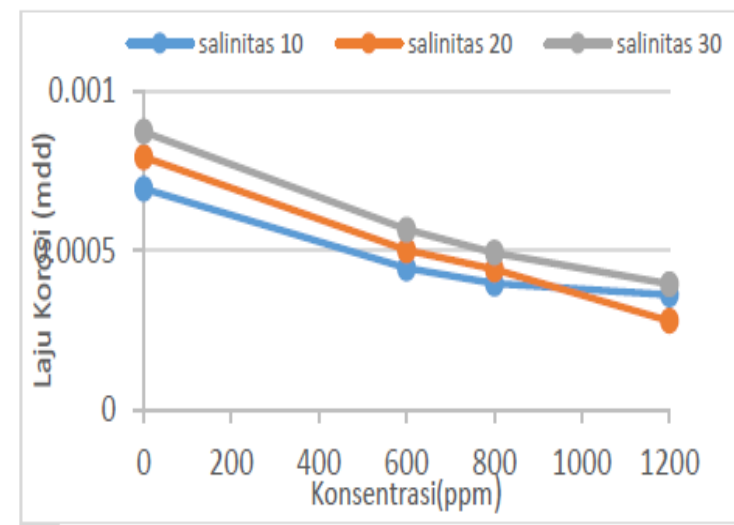

Gambar 6. Grafik hubungan konsentrasi inhibitor ekstrak kulit buah kakao terhadap laju korosi pada variasi salinitas

Laju korosi tanpa penambahan inhibitor menunjukkan nilai terbesar, dan merupakan pembanding yang digunakan untuk melihat pengaruh variasi penambahan konsentrasi inhibitor eksrak kulit buah kakao. Pada penambahan inhibitor $600 \mathrm{ppm}$ dan $800 \mathrm{ppm}$ menyebabkan penurunan laju korosi dibandingkan tanpa penambahan inhibitor. 
Hal ini menunjukkan adanya pengaruh inhibitorpada proses korosi besi, yang disebabkan oleh adanya lapisan tipis sebagai rotektf molekul-molekul teradsorbsi pada permukaan logam dalam larutan elektrolit (Ali, dkk. 2014).

Laju korosi terendah diperoleh pada penambahan inhibitor 1200 ppm dan salinitas $2,8 \times 10^{-5} \mathrm{mmd}$. Konsentrasi inhibitor ini merupakan jumlah yang efektifpada pembentukan senyaa kompleks yang dapat melindungi proses oksidasi pada logam besi. Konsentrasi inhibitor dapat mempengaruhi laju korosi jika sesuai dengan media korosif yang digunakan.

\section{SIMPULAN}

Berdasarkan hasil skrining fitokimia, ekstrak kulit biji kakao fraksi etanol $70 \%$ mengandung alkaloid, flavonoid, tanin, saponin, dan triterpenoid. Pengamatan menggunakan GC-MS menunjukkan terdapat 3 dari gologan benzene, 1 amida, 5 asam karboksilat, 3 monoterpen, 1 aromatik, 5 alkana, 3 alkohol 2 keton dan 1 steroaid.

Ekstrak kulit biji kakao dapat dimanfaatkan sebagai antimikroba karena kandungan komponen fitokimianya. Kandungan komponen fenoliknya seperti tanin dan flavonoid berpotensi sebagai sumber antioksidan alami.dan juga dapat berfungsi sebagai inhibitor terhadap laju korosi logam besi.

\section{UCAPAN TERIMA KASIH.}

Penulis pertama mengucapkan terimakasih pada Politeknik Negeri Padang atas Hibah Penelitian Unggulan Perguruan Tinggi dengan kontrak No. DIPA : 042.05. 28. 3421/2019.

\section{DAFTAR PUSTAKA}

[1] Agni Rimba Mawan, Sri Endah Indriwati, Suhadi. (2018). Aktivitas Anti bakteri Ekstrak Metanol Buah Syzygium polyanthum terhadap Pertumbuhan Bakteri Escherchiacoli. Bio eksperimen, Vol.4 (1), 64-68.
[2] Alemanno.L, T.Ramos, A. Gargadenec, C.Andary, and N. Ferriere, 2003, Lacalization and Identification of Phenolic Compounds in Theobroma cacao $L$ Somatic Embryogenesis, Annals of Botany, 92, 613-623.

[3] Ali, F., Saputri, D. Dan Nugroho, RF, (2014) "Pengaruh Waktu Perendaman dan Konsentrasi Ekstrak Daun Jambu Biji (Psidium guajava Linn) sebagai inhibitor terhadap laju korosi Baja SS 304 dalam larutan garam dan Asan, Teknik Kimia, 20(1): 28-37

[4] Andujar I, Recio M.C , Giner R.M and Rios J.L, 2012, Cocoa Poliphenol and Their Potential Benefits for Human Health, Oxidative Medicine and Cellular Longevity, HindawiPublishing Corporation, Vol. 2012, article ID. 906252, 23 pages.

[5] Chung. B. Y, Kenji Ilyama, and KangWan Han, 2003, Compositional Characterization of Cacao (Theobroma cacao L) Hull, Agriculture Chemical Bioethanol, 46 (1), 12-16.

[6] Figueira. A, and Janick, 2008, New products from Theobroma cacao. Seed pulp and pod gum, Advances in Botanical Research, 55, 885-892.

[7] Harborne. J. B., and Simmonds N.W, 1964, Phytochemical Dictionary: A Handbook of Bioactive Compounds from Plants, $2^{\text {nd }}$ edition, Academic Press, New York, 490-517.

[8] Helmestein. AM 2010, Theobromine Chemistry: Theobromine is Chocolates, diambil dari [http://chemistry.about.com/old/facts structures/a/theobrominechemistry.ht $\mathrm{m}]$.

[9] Hii C. L, C.L. Law, S. Suzannah, Misnawi and M. Cloke1, 2009, 
Polyphenols in Cocoa (Theobroma cacao L), AsianJournal of Food Agriculture Industri, 2 (4), 702-722.

[10] Kim, H and Keeney, P. G, 1983, Method of Analysis for (-) Epicatechin in Cocoa Beans by HPLC, Journal of Food Science, 48 (2), 548-551.

[11] Kurian, A. \& Sankar, M.A.(2007). Medicinal Plants: Vol.02.Horticulture Science Series. New India Publishing Agency (NIPA), New Delhi.

[12] M. Afdhal, Maming, St. Fauziah, “ Pemanfaatan Ekstraks Kulit Buah Kakao (Theobroma Cacao) sebagai Inhibitor pada Proses Korosi Besi" Artikel Penelitian

[13] Matsumoto M, Mikami M, and Kondo K, (2006), Separation of Organic Nitrogen Compounds by Supported Liquid Membranes Based on Ionic liquids, Journal Japan Petrolium Institute, 49, 256-261.

[14] Okuda T and H.Ito, 2011, Tannin of Constant Structure in Medical and Food Plant, Hydrolyzable Tannins and Polyphenol Related to Tannins, Journal of Moleculer Structure, 16, 2191-2217.

[15] Osman H, R. Nasarudin, S.L. Lee, 2004, Extracts of cocoa (Theobroma cacao L.) leaves and their antioxidation potential, Food Chemistry, 8 (6), 41-46.

[16] Raaman,N.(2006).PhytochemicalTech niques.NewIndiaPublishingAgency, $\mathrm{N}$ ewDelhi.

[17] Sastri. V. S, 2011, Adsorption in Corrosion Inhibition, Green Corrosion Inhibitor, Wiston Revie, Canada, pp.103-105.
[18] Shanab, S.M.M.. 2007. Antioxidant and Antibiotic Activities of Some Seaweeds (Egyptian Isolates). Agriculture and Biology, IX (2), 220225.

[19] Shanmugam,S.,Kumar,T.S.\&Selvam, K.P.(2010).Laboratory Handbook on Biochemistry. $\mathrm{PHI}$ LearningPrivateLimited,NewDelhi.

[20] Singh A, Singh V.K, and Quraishi, M.A, 2010, Aquos extrast of Kalmegh (Andrographis paniculata) Leaves as Green Inhibitor for mild steel in Hydrochloric. International Journal of Corrosion, 1-10.

[21] Singh A,I, E. E. Ebenso, and M. A. Quraishi, 2012, Corrosion Inhibition of Carbon Steel in $\mathrm{HCl}$ Solution by Some Plant Extracts, International Journal of Corrosion, 10, 1-20.

[22] Sri Mulyatni A, Budiani A dan Taniwiryono D, 2012, Aktivitas anti bakteri ekstrak kulit buah kakao (Theobroma cacao L.) terhadap Escherichia coli, Bacillus subtilis, dan Staphylococcus aureus, Menara Perkebunan, 80 (2), 77-84.

[23] Vermerris and Nicholson, 2006, Phenolic Compound Biochemistry, Springer, Netherland.

[24] Yetri Y, Emriadi, Jamarun N, Gunawarman, 2015, Corrosion inhibitor of mildsteel by polar extract of Theobroma cacao peelsinhydro chloric acid solution. Asian Journal of Chemistry, 27(3): 875-81 